\title{
Changes in Soil Properties and Enzymatic Activities Following Manure Applications to a Rangeland
}

\author{
Jourdan M. Bell, ${ }^{1}$ Clay A. Robinson, ${ }^{2}$ and Robert C. Schwartz ${ }^{3}$ \\ Authors are ${ }^{1}$ Graduate Research Assistant, US Department of Agriculture-Agricultural Research Service-Conservation and \\ Production Research Laboratory, PO Drawer 10, Bushland, TX 79012; ${ }^{2}$ Associate Professor, West Texas A\&M University, \\ 2501 4th Ave, Canyon, TX 79016; and ${ }^{3}$ Soil Scientist, US Department of Agriculture-Agricultural Research Service-Conservation \\ and Production Research Laboratory, PO Drawer 10, Bushland, TX 79012.
}

\begin{abstract}
Manure amendments to rangelands may alter soil functions related to nutrient recycling. We investigated the influence of grazing and cattle manure on soil carbon, nitrogen, Mehlich 3 phosphorus, and activities of alkaline phosphatase and dehydrogenase. Fertilizer treatments (unamended, manure, or urea + potassium dihydrogen phosphate $\left[\mathrm{KH}_{2} \mathrm{PO}_{4}\right]$ fertilizer) were imposed under grazed and nongrazed conditions in a short-grass native rangeland. Manure was applied at rates of $\sim 125 \mathrm{~kg} \mathrm{~N} \mathrm{ha}$ and $\sim 42 \mathrm{~kg}^{-1}$ $\mathrm{P} \mathrm{ha}{ }^{-1}$, and urea $+\mathrm{KH}_{2} \mathrm{PO}_{4}$ was applied at $75 \mathrm{~kg} \mathrm{~N}^{-1}$ and $20 \mathrm{~kg} \mathrm{P} \mathrm{ha}^{-1}$, respectively. Total aboveground biomass and soil samples at 4 depths $(0-200 \mathrm{~mm})$ were collected throughout 2 growing seasons. A controlled environment study also evaluated fertilizer source effects on enzymatic activities at $5 \mathrm{P}$ rates $\left(0-120 \mathrm{mg} \cdot \mathrm{kg}^{-1} \mathrm{P}\right.$ as manure or urea $\left.+\mathrm{KH}_{2} \mathrm{PO}_{4}\right)$. Amendments significantly $(P<0.05)$ increased extractable $\mathrm{P}$ following the second application for the 3 uppermost depth increments. Extractable P was greatest on manure-amended plots, increasing 44\% from February 1999 to July 2000 at the surface. However, increases in $\mathrm{P}$ extractability as a proportion of total $\mathrm{P}$ applied were similar for manure and $\mathrm{KH}_{2} \mathrm{PO}_{4}$. Enzymatic activities were significantly $(P<0.001)$ influenced by sampling date and soil depth. There were no consistent grazing effects on enzyme activities. Amendments did not influence dehydrogenase activities in the field; however, in the controlled environment, activities averaged $16 \%$ greater across all rates for manure-amended soil as compared with urea $+\mathrm{KH}_{2} \mathrm{PO}_{4}-$ amended soil $(P=0.025)$. Phosphatase activities increased significantly following manure applications under both field $(P=0.007)$ and controlled environment $(P=0.003)$ conditions. Elevated phosphatase activities following manure applications probably led to enhanced $\mathrm{P}$ mineralization and similar $\mathrm{P}$ extractabilities as a proportion of total $\mathrm{P}$ applied for manure- and $\mathrm{KH}_{2} \mathrm{PO}_{4}-\mathrm{amended} \mathrm{soils.}$ Therefore, when determining applications rates, total manure P should be considered bioavailable.
\end{abstract}

\section{Resumen}

La aplicación de estiércol en los pastizales puede alterar las funciones del suelo y el reciclaje de nutrientes. Investigamos la influencia del apacentamiento y estiércol del ganado sobre el carbón del suelo, nitrógeno, fósforo Mehlich 3 y las actividades de la fosfatasa alcalina y la dehidrogenasa. Se aplicaron tratamientos de fertilización (control sin fertilizante o estiércol, estiércol y fertilizante a base de urea $+\mathrm{KH}_{2} \mathrm{PO}_{4}$ ) a un pastizal nativo de zacates cortos con condiciones de apacentamiento y sin apacentamiento. El estiércol se aplicó en dosis de $\sim 125 \mathrm{~kg} \mathrm{~N}$ ha $^{-1} \mathrm{y} \sim 42 \mathrm{~kg} \mathrm{P}$ ha $^{-1}$ y la urea $+\mathrm{KH}_{2} \mathrm{PO}_{4}$ se aplicó en dosis de $75 \mathrm{~kg} \mathrm{~N} \mathrm{ha}^{-1}$ y $20 \mathrm{~kg} \mathrm{P} \mathrm{ha}^{-1}$, respectivamente. Muestras de biomasa aérea y de suelo a 4 profundidades $(0-200 \mathrm{~mm})$ se colectaron a lo largo de 2 estaciones de crecimiento. En un estudio bajo ambiente controlado también se evaluaron los efectos de la fuente de fertilizante sobre las actividades enzimáticas a 5 dosis de $\mathrm{P}\left(0-120 \mathrm{mg} \cdot \mathrm{kg}^{-1} \mathrm{P}\right.$ como estiércol o como urea $\left.+\mathrm{KH}_{2} \mathrm{PO}_{4}\right)$. Los fertilizantes incrementaron significativamente $(P<0.05)$ el fósforo extractable después de la segunda aplicación, en las 3 profundidades de suelo superiores. El fósforo extractable fue mayor en la superficie de las parcelas donde se aplicó el estiércol, aumentando $44 \%$ de Febrero de 1999 a Julio del 2000. Sin embargo, el aumento de la extractibilidad del P, en proporción al P total aplicado, fue similar para el estiércol y el $\mathrm{KH}_{2} \mathrm{PO}_{4}$. Las actividades enzimáticas fueron significativamente $(P<0.001)$ influenciadas por la fecha de muestreo y la profundidad del suelo. No hubo efectos consistentes del apacentamiento del ganado sobre la actividad enzimática. Los fertilizantes no influenciaron las actividades de la dehidrogenasa en el campo; sin embargo, en el ambiente controlado, las actividades promediaron $16 \%$ más, a través de todas las dosis, en los suelos con aplicación de estiércol en comparación con los que recibieron urea $+\mathrm{KH}_{2} \mathrm{PO}_{4}(P=0.025)$. Las actividades de la fosfatasa aumentaron significativamente después de la aplicación de estiércol, tanto en condiciones de campo $(P=0.007)$ como en ambiente controlado $(P=0.003)$. Las elevadas actividades de la fosfatasa después de la aplicación de estiércol probablemente condujeron a un aumento en la mineralización del $\mathrm{P}$ y a extractibilidades del P, con relación al P total aplicado, similares para suelos con aplicaciones de estiércol y $\mathrm{KH}_{2} \mathrm{PO}_{4}$. Por lo tanto, al determinar las dosis de aplicación, el $\mathrm{P}$ total del estiércol debe ser considerado biodisponible.

Key Words: phosphomonoesterase, dehydrogenase, short-grass rangeland, cattle manure, soil phosphorous

The mention of trade or manufacturer names is made for information purposes only and does not imply an endorsement, recommendation, or exclusion by USDA-ARS.

Correspondence: Jourdan M. Bell, Conservation and Production Laboratory, USDAARS, P0 Drawer 10, Bushland, TX 79012. Email: jbell@cprl.ars.usda.gov

Manuscript received 13 October 2005; manuscript accepted 26 February 2006.

\section{INTRODUCTION}

Accumulation of large quantities of manure in localized areas and the potential environmental consequences that may result from these nutrient concentrations have increased public 
pressure for more stringent environmental standards and greater restrictions on livestock operations. Traditionally, animal manures have been applied to cropland. However in many regions, manure use on cropland is limited because of soil $\mathrm{P}$ enrichment concerns and tighter regulations governing manure applications. Moreover, in many cattle-feeding localities, cropland comprises a small percentage of land use, which has led to generation of manure nutrients far in excess of crop requirements for $\mathrm{P}$ and the eventual stockpiling of manures (Stewart et al. 1998). Obviously, other viable options for manure disposal are required. Another alternative would be manure applications to land under permanent vegetation, such as rangelands.

Prolonged, annual manure applications can increase soil $\mathrm{N}$ and $\mathrm{P}$ accumulation, induce soil micronutrient deficiencies, and through the off-site transport of nutrients and microorganisms, increase associated environmental risks (Chang et al. 1991; Stewart et al. 1998; Sharpley et al. 2001). Additionally, increased $\mathrm{N}$ and $\mathrm{P}$ inputs can alter rangeland vegetative community composition (Richard and Redente 1995; Gillen and Berg 1998; Stavast et al. 2005), which, in turn, can influence soil properties. Microbial and biochemical properties are often among the most sensitive to management and changes in nutrient supply (Turco et al. 1994; Wood and Hattey 1995; Bandick and Dick 1999; Acosta-Martinez et al. 2003a, 2003b).

Amendment effects on enzyme activities and soil microbial populations are the result of a complex combination of the physical, chemical, and biological soil properties and processes (Tabatabai 1994). Previous studies have demonstrated that activities of dehydrogenase and phosphomonoesterases were stimulated by increased levels of organic matter (Juma and Tabatabai 1977; Martens et al. 1992; Goyal et al. 1993; Garcia et al. 1998). Similarly, Parham et al. (2002) demonstrated that, compared with inorganic fertilizers, long-term application of cattle manure to cropland increased dehydrogenase activities and enhanced activities of enzymes involved in $\mathrm{P}$ transformations, yet total $\mathrm{C}$ in amended soils remained unchanged. Parham et al. (2002) hypothesized that manure amendments promoted biological and microbial activities that accelerated $\mathrm{C}$ mineralization. In addition, the increase in alkaline phosphatase activities in manure-amended soils may have resulted from a concurrent increase in $\mathrm{pH}$ (Parham et al. 2002).

Although there are far fewer studies of enzyme activities on grassland as compared with cultivated soils, in general, enzyme activities tend to be greater in grassland than in cropland soils (Acosta-Martinez et al. 2003a). On rangelands, grazing intensity did not influence alkaline phosphatase activities, but, as with many studies, enzyme activities exhibited wide seasonal fluctuations (Banerjee et al. 2000). Because enzyme activities are associated with the soil profile and organic matter distribution, and thus, typically decrease with depth (Juma and Tabatabai 1977; Reddy et al. 1987; Tabatabai 1994; Vuorinen and Saharinem 1996), direct comparison with various studies comprising a range of sampling depths is difficult. Moreover, land-use practices (Acosta-Martinez et al. 2003b) coupled with clay mineralogy and environmental extremes (Lähdesmäki and Piispanen 1992) further complicate comparisons across depths and soils. Extracellular enzymes, such as alkaline phosphatases, can be stabilized by colloids, whereas dehydrogenase (an intracellular enzyme) is more susceptible to environmental extremes, such as heat and moisture stress (Burns 1982; Lähdesmäki and Piispanen
1992). A change in microbial functionality induced by inorganic and organic amendments may also affect the cycling of nutrients and the soil productivity (Parham et al. 2002). In this respect, the influence of manure amendments on organic carbon mineralization and $\mathrm{P}$ transformations in grasslands may be important with respect to identifying appropriate amendment rates on these soils. The objective of this study was to evaluate the effects of grazing, cattle manure, and inorganic fertilizer applications on aboveground biomass, soil chemical properties, and the enzyme activities of dehydrogenase and alkaline phosphatase in a rangeland soil. We hypothesized that enzymatic activities would change response to grazing and amendments, thereby influencing nutrient turnover.

\section{MATERIALS AND METHODS}

The field study was carried out on a native rangeland at the West Texas A\&M University Nance Ranch (lat $34^{\circ} 57^{\prime} \mathrm{N}$, long $101^{\circ} 47^{\prime} \mathrm{W}$ ) on an Olton clay loam (fine, mixed, superactive, thermic Aridic Paleustoll) with $0 \%-1 \%$ slopes. Main stripplots were established in February 1999 on an exclosure with a 3-year history without grazing and an adjacent grazed pasture. Within each main strip-plot, representing the grazing treatment, 3 fertilizer treatments (unamended, stockpiled beef cattle manure, and urea $+\mathrm{KH}_{2} \mathrm{PO}_{4}$ fertilizer) were established within a completely randomized design with 4 replications. Fertilizer applications and soil and plant sampling were restricted to established experimental units $(2.4 \mathrm{~m} \times 3.0 \mathrm{~m})$ within the main plots, whereas grazing occurred throughout the entire main plot. In 1999, the grazed main plot was stocked at 1.25 animal units $(\mathrm{AU}) \cdot \mathrm{ha}^{-1}$ from August through November and $1.04 \mathrm{AU} \cdot \mathrm{ha}^{-1}$ from April through July. Annual forage production was influenced by precipitation that was above normal in 1999 (615 mm) and below normal in 2000 (317 $\mathrm{mm})$, especially during the growing season. The principal plant species for this rangeland site (Bell 2000) were purple threeawn (Aristida purpurea, Nutt.), blue grama (Boutelona gracilis, H.B.K.), and buffalo grass (Buchloë dactyloides, Nutt.).

Fertilizer and manure were applied in March 1999 and 2000. Bulk samples of manure were collected each year from an old (> 1 year) stockpile in a beef cattle feed yard (high-concentrate diet) located near Amarillo, TX. Air-dried manure was ground to improve material uniformity and broadcast onto plots at a rate of approximately $125 \mathrm{~kg} \mathrm{~N} \mathrm{ha}^{-1}$ and $42 \mathrm{~kg} \mathrm{P} \mathrm{ha}^{-1}$ (Table 1). Urea $+\mathrm{KH}_{2} \mathrm{PO}_{4}$ was dissolved in water and applied with a hand-sprayer to achieve application rates of $75 \mathrm{~kg} \mathrm{~N} \mathrm{ha}^{-1}$ and $20 \mathrm{~kg} \mathrm{P} \mathrm{ha}^{-1}$. Manure was applied at a higher total $\mathrm{N}$ rate on manure plots compared with inorganic fertilizer plots to account for incomplete $\mathrm{N}$ mineralization during the growing season (Eghball 2000). We applied $20 \mathrm{~kg} \cdot \mathrm{ha}^{-1}$ of inorganic P (approximately half that of the manure treatment) to avoid $\mathrm{P}$ loading, as additional $\mathrm{P}$ would not be used by the grasses.

Soil samples were collected in February 1999 before fertilizer applications and subsequently in July 1999, April 2000, and July 2000. Six 25-mm-diameter soil samples were collected from each experimental plot and composited by depth at $0-25,25-50,50-100$, and $100-200 \mathrm{~mm}$ increments. Samples were ground by hand, sieved $(2.0 \mathrm{~mm})$, and stored at 
$4^{\circ} \mathrm{C}$ before analyses. Soil samples were not air-dried because of the varying effects of air-drying on soil enzyme activities (Speir and Ross 1978; Tabatabai 1994). Oven-dry-equivalent soil weights were used for all assays. End-of-season, aboveground plant biomass samples were collected in October 1999 and September 2000. In each plot, $20.25-\mathrm{m}^{2}$ quadrats were clipped and biomass dry weight was determined following oven-drying at $60^{\circ} \mathrm{C}$ for $24 \mathrm{~h}$.

Soil samples $(0-25 \mathrm{~mm})$ were collected from unamended subplots and composited in both the grazed and nongrazed main plots, in January 2001, for a controlled environment study. Soils were passed through a $2-\mathrm{mm}$ sieve and incubations were completed using 70-g-equivalent oven-dry soil in ventilated plastic containers. Soil in each container was amended with stockpiled manure or inorganic fertilizer at 5 rates $(0,20$, 40, 80, and $120 \mathrm{mg} \mathrm{P} \mathrm{kg}^{-1}$ ). Ground manure (0.5-mm sieve) with an N:P ratio of 3.1 (Table 1) was added to soil containers at the 5 treatment rates and mixed with the soil using a glass rod. Inorganic fertilizer consisted of a solution of urea and $\mathrm{KH}_{2} \mathrm{PO}_{4}$ with an $\mathrm{N}$ :P ratio of 3.0. Amended experimental units were replicated 3 times. In contrast, unamended $\left(0 \mathrm{mg} \mathrm{P} \mathrm{kg}^{-1}\right)$ experimental units were replicated 6 times to establish a baseline, with a small error, from which enzymatic activities would be expected to diverge as compared with amended soils. The soil water content in containers was adjusted to $-33 \mathrm{kPa}$ with deionized water and samples were incubated for 1 week at $25^{\circ} \mathrm{C}$ and 1 week at $40^{\circ} \mathrm{C}$. The wet-dry cycle was used because it can influence both microbial populations in the soil (Salema et al. 1982) and the adsorption and desorption of phosphate (Haynes and Swift 1985). Furthermore, this regime more closely approximates field conditions. Upon completion of each 2-week cycle, deionized water was added to attain a water potential of $-33 \mathrm{kPa}$. After the 8 -week incubation, samples were ground to pass through a $2-\mathrm{mm}$ sieve and stored at $4^{\circ} \mathrm{C}$ for later analyses.

Total elemental $\mathrm{C}$ and $\mathrm{N}$ in manures and soils were determined by dry combustion at $1300^{\circ} \mathrm{C}$ and subsequent analyses of evolved gases using a LECO CNS-2000 analyzer (LECO Corp., St. Joseph, MI). Manures were digested with sulfuric acid and hydrogen peroxide for determination of total $\mathrm{P}$ in digests (Richards 1993). Soil phosphorus was extracted with the Mehlich 3 extractant (Mehlich 1984; $2 \mathrm{~g}$ of soil in $20 \mathrm{~mL}$, shaken end over end for 5 minutes, and filtered through Whatman No. 2 filter paper). Soil extractable $\mathrm{NO}_{3}-\mathrm{N}$ and $\mathrm{NH}_{4}-\mathrm{N}$ were determined using a $2.0-\mathrm{M} \mathrm{KCl}$ extracting solution (Keeney and Nelson 1982; 2 g of soil in $20 \mathrm{~mL}$, shaken end over end for 10 minutes, and filtered through Whatman No. 2 filter paper). Dissolved molybdate-reactive P in extracts and digest were determined using a modified colorimetric molybdate-blue method (Murphy and Riley 1962; US EPA 1983) in conjunction with a Flow III autoanalyzer (OI Analytical, College Station, TX). Nitrate-nitrogen was determined in soil extracts using the automated cadmium reduction procedure (US EPA 1983). Ammonium-nitrogen in soil extracts was determined using the automated salicylic analog of the indophenol blue method (US EPA 1983).

Dehydrogenase activity was determined by the amount of 2,3,5-triphenyl formazan (TPF) released by the reduction of 2,3,5-triphenyltetrazolium chloride combined with soil and calcium carbonate after a 24 -hour incubation of soil at $37^{\circ} \mathrm{C}$
Table 1. Properties of manure samples applied to rangeland soils at West Texas A\&M University Nance Ranch for field and controlled environment studies. ${ }^{1}$

\begin{tabular}{|c|c|c|c|c|c|}
\hline & $\begin{array}{c}\text { Manure } \\
\text { application rate }\end{array}$ & Total N & Total P & $\begin{array}{l}\mathrm{N}: \mathrm{P} \\
\text { ratio }\end{array}$ & $\begin{array}{l}\text { Water } \\
\text { content }\end{array}$ \\
\hline & $\mathrm{kg} \cdot \mathrm{ha}^{-1}$ & \multicolumn{2}{|c|}{----- g g kg ${ }^{-1}-----$} & & \\
\hline 1999, Field ${ }^{2}$ & 5850 & 20.6 & 7.40 & 2.78 & 0.244 \\
\hline 2000, Field & 6390 & 19.8 & 6.22 & 3.18 & 0.193 \\
\hline 2001, Controlled & & & & & \\
\hline environment $^{3}$ & $N A^{4}$ & 19.4 & 6.26 & 3.10 & 0.161 \\
\hline
\end{tabular}

${ }^{1}$ All concentrations are on a dry-matter basis and represent an average of 5 samples.

${ }^{2}$ Manure applied in situ to rangeland soils.

${ }^{3}$ Soil samples were collected from rangeland, amended, and subjected to an 8-wk controlledenvironment incubation before analysis.

${ }^{4}$ Controlled-environment soils were amended at 5 rates $\left(0,20,40,80\right.$, and $\left.120 \mathrm{mg} \cdot \mathrm{kg}^{-1} \mathrm{P}\right)$.

and extraction with methanol (Tabatabai 1994). The concentration of TPF in methanol was determined using a colorimeter at a wavelength of $485 \mathrm{~nm}$. Alkaline phosphatase activity was determined by incubating $1 \mathrm{~g}$ of soil with a buffer solution $(\mathrm{pH}$ 11.0) and $p$-nitrophenol phosphate solution for 1 hour at $37^{\circ} \mathrm{C}$. Following incubation and addition of $\mathrm{CaCl}_{2}$ and $\mathrm{NaOH}$, the suspension was filtered and analyzed for $p$-nitrophenol released using a colorimeter at $420 \mathrm{~nm}$ (Tabatabai and Bremner 1969).

Statistical analyses of variance for soil and biomass data were determined at each sampling date and soil depth using a mixed-linear model analysis for a split-plot design (Littell et al. 1996). Significance of spatial (soil depth) and temporal (sampling date) effects were determined using mixed-linear model analysis in conjunction with a heterogeneous autoregressive covariance structure for repeated measurements. Grazing and fertilizer treatments were designated as fixed effects and plot replicates were designated as random effects. Grazed and nongrazed main plots were analyzed separately for aboveground biomass because grazed plots represent a net removal of forage. For the 8-week controlled-environment study, P source and application rate were also designated as fixed effects. Orthogonal contrasts were used to test for differences among selected mean comparisons. For all statistical analyses, effects were declared significant at the 0.05 probability level.

\section{RESULTS AND DISCUSSION}

Soil properties of initial samples collected in February 1999 exhibited no significant $(P>0.05)$ statistical differences between grazing treatments with the exception of total carbon and total nitrogen (Table 1). Total $\mathrm{C}$ and total $\mathrm{N}$ were significantly greater $(P=0.025$ and 0.011 , respectively $)$ in the 0-25-mm samples under nongrazed conditions (Table 2). Banerjee et al. (2000) and Wienhold et al. (2001) have also reported lower soil organic carbon content in pastures subjected to greater grazing intensities.

Aboveground biomass remaining at the end of the growing season on both grazed and nongrazed sites was consistently greater for amended plots than plots receiving no amendments. Similarly, Stavast et al. (2005) also found that aboveground biomass increased with manure applications at comparable rates $\left(54 \mathrm{~kg} \mathrm{P} \mathrm{ha}^{-1}\right)$ under nongrazed conditions. However in this study, this trend was significant $(P=0.005)$ only for the 
Table 2. Mean and standard error of initial soil properties in samples from February 1999 on an Olton clay loam (fine, mixed thermic Aridic Paleustoll) with a $0 \%-1 \%$ slope at West Texas A\&M University Nance Ranch.

\begin{tabular}{|c|c|c|c|c|c|c|c|c|c|c|}
\hline Depth & $\begin{array}{c}\text { Mehlich } 3 \\
\text { phosphorus }\end{array}$ & $\mathrm{NO}_{3}-\mathrm{N}$ & $\mathrm{NH}_{4}-\mathrm{N}$ & Total N & Total C & $\begin{array}{l}\text { Dehydrogenase } \\
\text { formazan }\end{array}$ & $\begin{array}{c}\text { Alkaline } \\
\text { phosphatase } \\
\text { p-nitrophenol }\end{array}$ & Clay $^{1}$ & Sand & $\mathrm{pH}$ \\
\hline $\mathrm{mm}$ & \multicolumn{3}{|c|}{ - } & \multicolumn{2}{|c|}{------- g·kg ${ }^{-1}-------$} & $\mathrm{mg} \cdot \mathrm{kg}^{-1}\left(24 \mathrm{~h}^{-1}\right)$ & $\mathrm{mg} \cdot \mathrm{kg}^{-1} \mathrm{~h}^{-1}$ & \multicolumn{2}{|c|}{------ \% ------- } & \\
\hline \multicolumn{11}{|l|}{ Nongrazed } \\
\hline $0-25$ & $44.7 \pm 3.5$ & $8.5 \pm 2.5$ & $12.8 \pm 1.3$ & $2.6 \pm 0.2$ & $28.0 \pm 1.6$ & $31.4 \pm 1.7$ & $19.8 \pm 1.1$ & 18.45 & 70.27 & $6.09 \pm 0.13$ \\
\hline $25-50$ & $18.2 \pm 0.9$ & $20.6 \pm 3.3$ & $7.2 \pm 2.0$ & $1.8 \pm 0.1$ & $19.3 \pm 0.9$ & $18.4 \pm 0.9$ & $13.8 \pm 1.2$ & 20.44 & 68.31 & $6.32 \pm 0.11$ \\
\hline $50-100$ & $12.9 \pm 0.2$ & $16.0 \pm 1.9$ & $3.1 \pm 0.7$ & $0.9 \pm 0.04$ & $10.4 \pm 0.5$ & $15.4 \pm 0.8$ & $11.1 \pm 0.8$ & 20.38 & 69.43 & $6.57 \pm 0.08$ \\
\hline $100-200$ & $9.9 \pm 0.2$ & $9.6 \pm 0.2$ & $4.9 \pm 1.3$ & $0.8 \pm 0.03$ & $8.5 \pm 0.3$ & $12.1 \pm 0.6$ & $16.1 \pm 1.7$ & 16.24 & 74.63 & $6.73 \pm 0.11$ \\
\hline \multicolumn{11}{|l|}{ Grazed } \\
\hline $0-25$ & $48.3 \pm 11.4$ & $4.8 \pm 0.1$ & $15.6 \pm 4.7$ & $1.7 \pm 0.1$ & $20.2 \pm 2.1$ & $33.4 \pm 2.1$ & $16.1 \pm 2.3$ & 20.49 & 61.06 & $6.16 \pm 0.08$ \\
\hline $25-50$ & $25.8 \pm 6.1$ & $10.6 \pm 2.2$ & $16.4 \pm 5.3$ & $1.6 \pm 0.1$ & $16.5 \pm 1.1$ & $19.3 \pm 0.8$ & $14.4 \pm 1.6$ & 22.52 & 62.13 & $6.53 \pm 0.11$ \\
\hline $50-100$ & $15.7 \pm 0.2$ & $11.0 \pm 1.4$ & $12.7 \pm 2.9$ & $0.8 \pm 0.1$ & $9.8 \pm 0.3$ & $16.3 \pm 0.9$ & $12.5 \pm 1.6$ & 18.34 & 68.42 & $6.74 \pm 0.12$ \\
\hline 100-200 & $10.5 \pm 0.8$ & $6.0 \pm 0.2$ & $10.2 \pm 2.2$ & $0.7 \pm 0.1$ & $8.0 \pm 0.4$ & $12.2 \pm 0.8$ & $15.4 \pm 1.7$ & 16.22 & 76.68 & $6.82 \pm 0.05$ \\
\hline
\end{tabular}

${ }^{1}$ Soil texture was determined using composited samples for each soil depth and site. Clay was determined using the hydrometer method and the sand fraction was determined by sieving (270 mesh).

grazed plots in 2000. Soil $\mathrm{NO}_{3}-\mathrm{N}, \mathrm{NH}_{4}-\mathrm{N}$, and total $\mathrm{N}$ were not correlated with aboveground biomass for all years on the nongrazed site (data not shown). Early season soil $\mathrm{NO}_{3}-\mathrm{N}$ and $\mathrm{NH}_{4}-\mathrm{N}$ concentrations at the $0-25-\mathrm{mm}$ depth increment in April 2000, 1 month following amendments, were significantly $(P=0.008$ and 0.007 , respectively) greater for plots receiving urea $+\mathrm{KH}_{2} \mathrm{PO}_{4}$ as compared with manure-treated plots (11.9 vs. $5.4 \mathrm{mg} \cdot \mathrm{kg}^{-1}$ for $\mathrm{NO}_{3}-\mathrm{N}$ and 21.5 vs. $10.6 \mathrm{mg} \cdot \mathrm{kg}^{-1}$ for $\mathrm{NH}_{4}-\mathrm{N}$ ). This is a typical response to inorganic and organic fertilizer application because urea is more easily converted to $\mathrm{NO}_{3}-\mathrm{N}$ and $\mathrm{NH}_{4}-\mathrm{N}$ compared with manure-N (Schwartz et al. 2003). By the last sampling date in July 2000, there were no significant differences in soil $\mathrm{NH}_{4}-\mathrm{N}$ and $\mathrm{NO}_{3}-\mathrm{N}$ due to amendments for the $0-25-\mathrm{mm}$ depth increment $(5.07$ vs. $8.14 \mathrm{mg} \cdot \mathrm{kg}^{-1}$ for $\mathrm{NO}_{3}-\mathrm{N}$ and 6.95 vs. $10.32 \mathrm{mg} \cdot \mathrm{kg}^{-1}$ for $\mathrm{NH}_{4}-\mathrm{N}$ ). Transitory responses of soil $\mathrm{NO}_{3}-\mathrm{N}$ and $\mathrm{NH}_{4}-\mathrm{N}$ to $\mathrm{N}$ inputs are probably a result of active $\mathrm{N}$ uptake by perennials



Figure 1. Changes in extractable $P$ with time at 2 sampling depth increments. Error bars are $\pm 1 \mathrm{SE}$. combined with infrequent sampling dates and seasonal fluctuations of microbial activity.

In the field study, Mehlich 3-extractable P was not influenced by grazing across all sampling dates and depths. However, in April and July of 2000, there was a significant fertilizer treatment effect for extractable $\mathrm{P}(P<0.05)$ at the $0-25,25-50$, and $50-100-\mathrm{mm}$ depth increments. Levels of extractable $\mathrm{P}$ diverged with respect to fertilizer treatments such that unamended $<$ urea $+\mathrm{KH}_{2} \mathrm{PO}_{4}<$ manure for these depth increments and sampling dates (Fig. 1). Moreover, differences among the 3 fertilizer treatments were all significant $(P<0.05)$ on the last sampling date. At the $0-25-\mathrm{mm}$ depth increment, extractable $\mathrm{P}$ on manure-amended plots increased $44 \%$ from February 1999 to July 2000 (Fig. 1). Consistently greater Mehlich 3-extractable $\mathrm{P}$ on plots amended with manure as compared with urea $+\mathrm{KH}_{2} \mathrm{PO}_{4}$ is obviously a consequence of higher P-loading rates (Fig. 1). Increases in extractable $\mathrm{P}$ $(0-200 \mathrm{~mm})$ as a fraction of the total $\mathrm{P}$ applied for 2 seasons were similar for manure $(24.4 \%)$ and inorganic fertilizer (24.8\%). Schwartz and Dao (2005) also found that Mehlich 3-P extractabilities in a Paleustoll amended with scraped cattle manure were similar to $\mathrm{KH}_{2} \mathrm{PO}_{4}$-amended soil applied at the same rate when incubated for 8 weeks under controlled wettingdrying conditions. However, the percentages of extractable $\mathrm{P}$ as a proportion of total $\mathrm{P}$ applied reported by Schwartz and Dao (2005) were considerably greater $(68 \%$ and $79 \%$ for manure and $\mathrm{KH}_{2} \mathrm{PO}_{4}$, respectively) than in this study, even considering an estimated forage uptake of $0.5 \mathrm{~kg} \mathrm{P} \mathrm{ha}{ }^{-1} \cdot \mathrm{yr}^{-1}$ for the 2 seasons. Lower application rates in conjunction with initially lower $\mathrm{P}$ extractabilities and longer time periods between applications and sampling dates are likely responsible for the lower recovery rates in this study.

Levels of dehydrogenase activity in this study ranged from 2 to 51 and from 11 to $43 \mathrm{mg}$ formazan $\mathrm{kg}^{-1} \cdot 24 \mathrm{~h}^{-1}$ in the field and in controlled environment, respectively (Fig. 2). These levels fall within the range reported by Parham et al. (2002) for a similar cropland soil (Udertic Paleustoll). Dehydrogenase activity varied significantly $(P<0.001)$ with time (sampling 

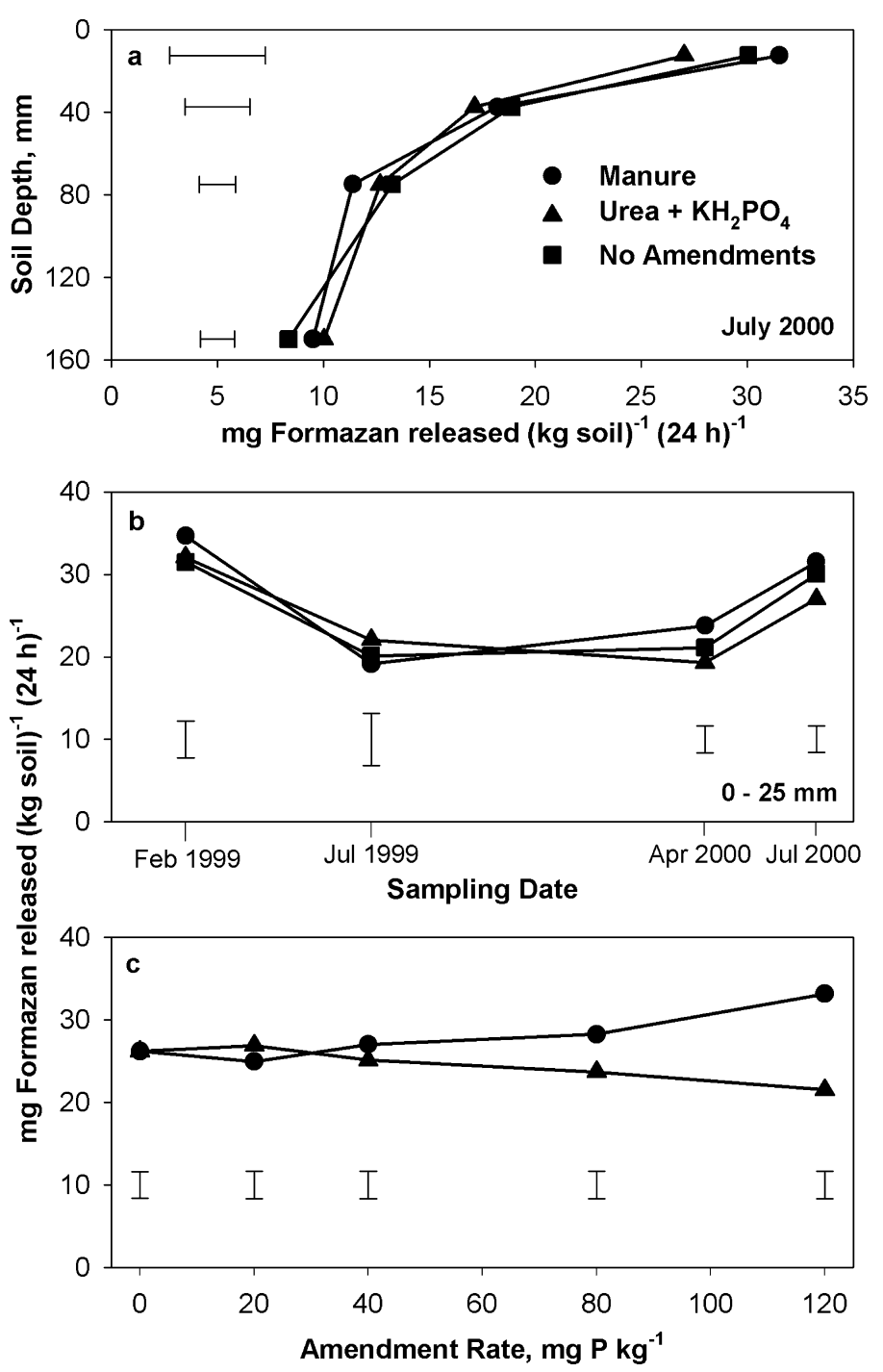

Figure 2. Dehydrogenase activity a, in relation to soil depth in July 2000 in the field across grazing treatments, $\mathbf{b}$, with respect to sampling date at 0-25 $\mathrm{mm}$ in the field across grazing treatments, and $\mathbf{c}$, as a function of the phosphorus-amendment rate in the controlled environment study. Error bars are $\pm 1 \mathrm{SE}$ of the least square means from mixed-linear model analysis.

date) at all sampling depths, independent of fertilizer treatments. Additionally, dehydrogenase activity varied significantly $(P<0.001)$ with respect to soil depth for all sampling dates (Fig. 2). Dehydrogenase activities in the field did not exhibit a significant response to fertilizers (Fig. 2) and exhibited no consistent effect in response to grazing (data not shown). In contrast, dehydrogenase activities in the controlled environment study were significantly $(P=0.025)$ influenced by fertilizer source. There was a nonsignificant trend for dehydrogenase activity to increase with increasing rates of manure and to decrease with increasing rates of urea $+\mathrm{KH}_{2} \mathrm{PO}_{4}$. At a rate of $120 \mathrm{mg} \mathrm{P} \mathrm{kg}{ }^{-1}$, dehydrogenase activities were $54 \%$ greater in manure-amended soils than urea $+\mathrm{KH}_{2} \mathrm{PO}_{4}$-amended soils (Fig. 2). Activities of dehydrogenases have typically increased with additions of organic substrates (Frankenberger and Dick 1983; Tabatabai 1994; Bandick and Dick 1999). In our field
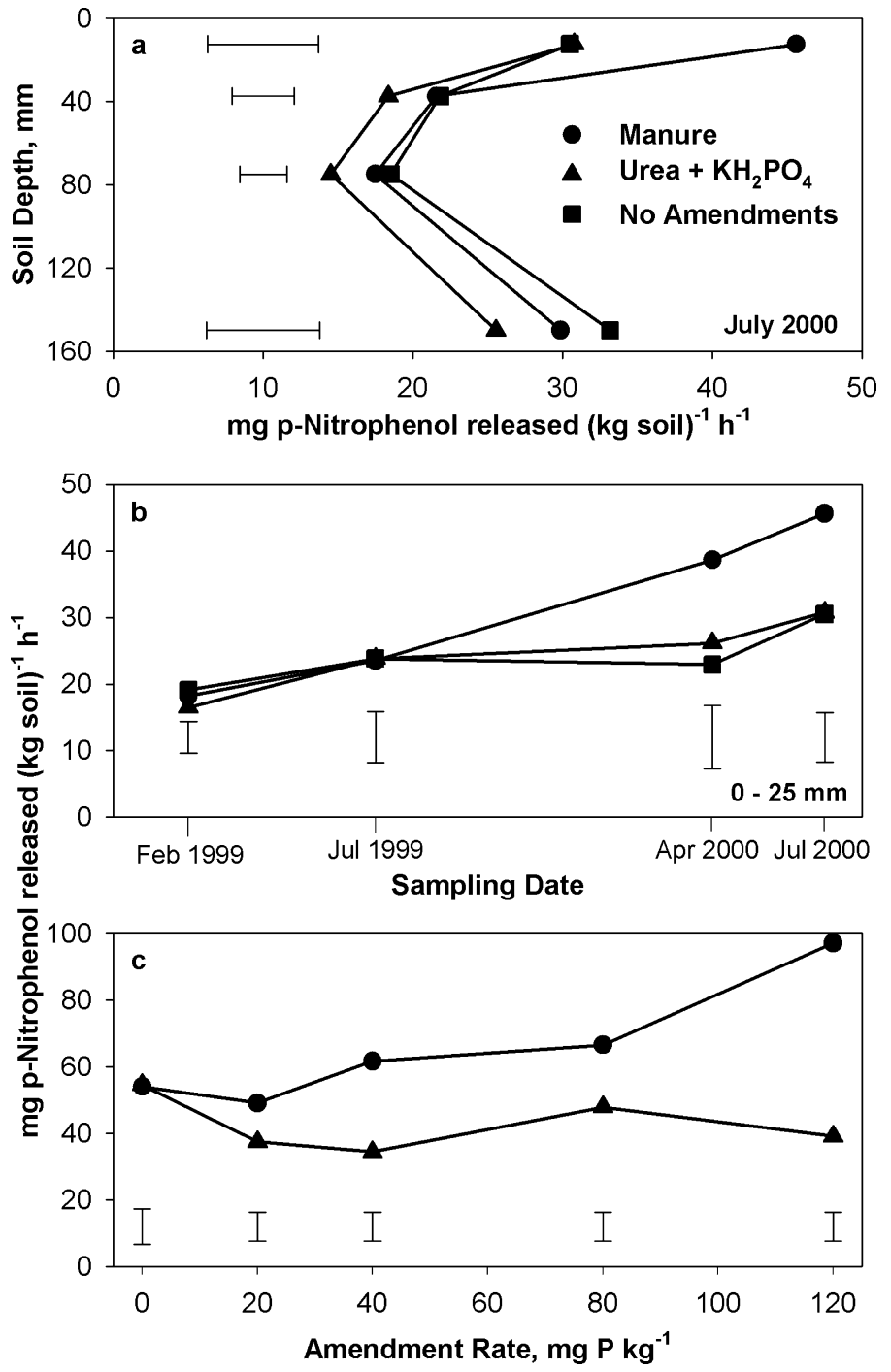

Figure 3. Alkaline phosphatase activity a, in relation to soil depth in July 2000 in the field across grazing treatments, $\mathbf{b}$, with respect to sampling date at $0-25 \mathrm{~mm}$ in the field across grazing treatments, and c, as a function of the phosphorus-amendment rate in the controlled environment study. Error bars are $\pm 1 \mathrm{SE}$ of the least square means from mixed-linear model analysis.

study, soil samples were collected 1-4 months following fertilizer amendments. The lack of response in the field may be the result of the timing of soil collection, coupled with shortlived increases in dehydrogenase activities in response to substrate additions. Seasonal fluctuations in temperature and precipitation have also been shown to influence dehydrogenase activities (Diaz-Marcote and Ceccanti 1995). Beyer et al. (1993) also concluded that dehydrogenase activity varied significantly over a uniform field and hindered valid ecological comparisons of soils.

Alkaline phosphatase activities in this study ranged from 1 to 74 and 20 to $130 \mathrm{mg} p$-nitrophenol $\mathrm{kg}^{-1} \cdot \mathrm{h}^{-1}$ for the field and controlled environment studies, respectively (Fig. 3). The range of our field results was similar to activities reported by Parham et al. (2002) for a Paleustoll. Analogous to other studies (e.g., Juma and Tabatabai 1978; Frankenberger and 
Dick 1983) alkaline phosphatase activity and total soil organic carbon were positively correlated $(r=0.721, P<0.001)$. Sampling date significantly $(P<0.001)$ influenced alkaline phosphatase activities in the field. Alkaline phosphatase activities on manure-amended plots averaged $48 \%$ greater $(P<0.007)$ than $\mathrm{KH}_{2} \mathrm{PO}_{4}+$ urea-amended plots at the $0-25-\mathrm{mm}$ depth increment for the final 2 sampling dates (Fig. 3). Similarly, alkaline phosphatase activities in the controlled environment study increased with increasing manure application rates $(P=0.003)$, whereas changes in activity in response to inorganic fertilizer rates were nonsignificant $(P=0.084)$. Enhanced alkaline phosphatase activities in response to manure applications have also been reported by Parham (2002). Grazing did not significantly influence alkaline phosphatase activities in the field (data not shown). Similarly, Banjeree et al. (2000) reported that grazing intensity did not influence alkaline phosphatase activities. In contrast, mean alkaline phosphatase activities on grazed sites averaged $53 \%$ greater $(P<0.001)$ than on nongrazed sites in the controlled environment study (data not shown).

For all sampling dates and treatments, alkaline phosphatase activities decreased with increasing soil depth to the 50-100-mm increment (Fig. 3). High alkaline phosphatase activity at the 0-25-mm depth increment was likely a result of greater biological activity associated with high levels of soil organic carbon near the surface (Speir and Ross 1978). Conversely, at the lowest depth, activities were nearly double the levels measured at the 50-100-mm depth increment (Fig. 3). Previous studies demonstrated a positive relationship between $\mathrm{pH}$ and alkaline phosphatase activities (Juma and Tabatabai 1977; Parham et al. 2002). However, in this study, $\mathrm{pH}$ probably had only a partial influence on differences in alkaline phosphatase activities between these 2 layers because differences in $\mathrm{pH}$ were small $(0.13)$ (Table 2). Greater activities in the 100 200-mm depth increment may have also resulted from smaller clay contents in this zone (Table 2) concomitant with evidence of phosphomonoesterase deactivation by clays (Speir and Ross 1978). In addition, a more favorable soil moisture regime at this lower depth may have enhanced alkaline phosphatase activities over the long term as compared with the 25100-mm zone.

\section{CONCLUSIONS AND MANAGEMENT IMPLICATIONS}

Aboveground biomass responded positively to manure and fertilizer amendments; however, these responses were not correlated with soil $\mathrm{NO}_{3}-\mathrm{N}, \mathrm{NH}_{4}-\mathrm{N}$, and total $\mathrm{N}$ levels. Greater levels of $\mathrm{NO}_{3}-\mathrm{N}$ concomitant with greater total $\mathrm{C}$ and $\mathrm{N}$ under nongrazed as compared with grazed conditions suggest that, for these application rates and the short-term duration of this study, the effects of amendments on soil $\mathrm{NO}_{3}-$ $\mathrm{N}$ concentrations were transitory and governed principally by mineralization rates of the native soil organic carbon. Mehlich 3 -extractable $\mathrm{P}$ was not affected by grazing but increased $44 \%$ following 2 applications of manure. Increases in extractable $\mathrm{P}$ relative to P-amendment rates were similar for manure and inorganic fertilizer applications and averaged approximately one-quarter of the total $\mathrm{P}$ applied. For this soil and loading rates, Mehlich 3-extractable P slowly increased in response to manure amendments probably because of an initially low $P$ status. With subsequent fertilizer applications, Mehlich 3 would be expected to increase more rapidly because of increases in soil $\mathrm{P}$ saturation.

Alkaline phosphatase activity increased in concert with manure additions, apparently leading to enhanced mineralization of added organic P and similar P extraction efficiencies between organic and inorganic sources. Enhanced mineralization rates of the added manure organic $P$ fraction imply that, similar to soluble inorganic $\mathrm{P}$ fertilizers, the total $\mathrm{P}$ (inorganic + organic) should be considered available when determining conservative application rates.

Neither alkaline phosphatase nor dehydrogenase activities exhibited consistent responses to grazing. Manure amendments increased alkaline phosphatase activities, whereas dehydrogenase activities in the field were not significantly different among fertilizer treatments. Dissimilar enzymatic activity responses to fertilizer treatments may be the result of the resiliency of the respective enzymes to external perturbations. Alkaline phosphatase, an extracellular enzyme, may have exhibited more resiliency under soil moisture and temperature stresses as compared with dehydrogenase, an intracellular enzyme. Consequently, environmental extremes in the field study probably masked fertilizer treatment effects on dehydrogenase activities. In this respect, measured alkaline phosphatase activities probably reflect longer-term (i.e., seasonal or yearly) variations in $\mathrm{P}$ mineralization. Although alkaline phosphatase activity was responsive to fertilizer treatments, its use as an indicator of soil function for comparisons among diverse soils is compromised because of the dependence of activities with organic carbon, $\mathrm{pH}$, and texture. Because Mehlich 3-extractable P was the most sensitive to manure additions compared with other soil parameters examined, it is recommended that extractable $\mathrm{P}$ tests be performed regularly to monitor P loading. This would enable producers to maintain rangeland productivity and minimize off-site impacts by optimizing timing and rate of applications and facilitating waste-use contracts with confined animal feeding operations to meet nutrient application standards.

\section{ACKNOWLEDGMENTS}

We gratefully acknowledge Dr Thanh Dao (USDA-ARS, Beltsville) for initial guidance in the planning of this study. We also gratefully acknowledge the assistance of Mr Guy Bell, Mr Grant Johnson, Mr Larry Fulton, and $\mathrm{Mr}$ Wade Davis in various phases of the research.

\section{LITERATURE CITED}

Acosta-Martinez, V., S. Klose, and T. M. Zobeck. 2003a. Enzyme activities in semiarid soils under conservation reserve program, native rangeland, and cropland. Journal of Plant Nutrition and Soil Science 166:699-707.

Acosta-Martinez, V., T. M. Zobeck, T. E. Gill, and A. C. Kennedy. 2003b. Enzyme activities and microbial community structure in semiarid agricultural soils. Biology and Fertility of Soils 38:216-227.

Bandick, A. K., AND R. P. Dick. 1999. Field management effect on soil enzyme activities. Soil Biology and Biochemistry 31:1471-1479.

Banjeree, M. R., D. L. Burton, W. P. McCaughey, and C. A. Grant. 2000. Influence of pasture management on soil biological quality. Journal of Range Management 53:127-133. 
BeLL, J. M. 2000. Stockpiled beef manure effects on soil enzymatic activities on a short-grass rangeland [MS thesis]. Canyon, TX: West Texas A\&M University.

Beyer, L., C. Wachendorf, D. C. Elsner, and R. Knabe. 1993. Suitability of dehydrogenase activity assay as an index of soil biological activity. Biology and Fertility of Soils 16:52-56.

BuRns, R. G. 1982. Enzyme activity in soil: location and possible role in microbial ecology. Soil Biology and Biochemistry 14:423-427.

Chang, C., T. G. Sommerfeldt, and T. Entz. 1991. Soil chemistry after eleven annual applications of cattle feedlot manure. Journal of Environmental Quality 20: 475-480.

Diaz-Marcote, I., and B. Ceccanti. 1995. Enzymatic activities in a soil amended with organic wastes at semiarid field conditions. Arid Soil Research and Rehabilitation 9:317-325.

EghBALL, B. 2000. Nitrogen mineralization from field-applied beef cattle feedlot manure or compost. Soil Science Society of America Journal 64:2024-2030.

Frankenberger, W. T., JR., And W. A. Dick. 1983. Relationships between enzyme activities and microbial growth and activity indices in soil. Soil Science Society of America Journal 47:945-951.

Garcia, C., T. Hernandez, J. Albaladejo, V. Castillo, and A. Roldan. 1998. Revegetation in semiarid zones: influence of terracing and organic refuse on microbial activity. Soil Science Society of America Journal 62:670-676.

Gillen, R. L., AND W. A. Berg. 1998. Nitrogen fertilization of a native grass planting in western Oklahoma. Journal of Range Management 51:436-441.

Goyal, S., M. M. Mirsha, S. S. Dhankar, K. K. Kapoor, and R. Barta. 1993. Microbial biomass turnover and enzyme activities following the application of farmyard manure to field soils with and without previous long-term applications. Biology and Fertility of Soils 15:60-64.

HAYneS, R. J., AND R. S. Swift. 1985. Effects of air-drying on the adsorption and desorption of phosphate and levels of extractable phosphate in a group of acid soils, New Zealand. Geoderma 35:145-157.

Juma, N. G., And M. A. TABatabal. 1977. Effects of trace elements on phosphatase activity in soils. Soil Science Society of America Journal 41:343-346.

Juma, N. G., AND M. A. Tabatabal. 1978. Distribution of phosphomonoesterase in soils. Soil Science 126:101-108.

Keeney, D. R., and D. W. Nelson. 1982. Nitrogen-Inorganic forms. In: A. L. Page, R. H. Miller, and D. R. Keeney [EDs.]. Methods of soil analysis, part 2: Chemical and microbiological properties. Madison, Wl: American Society of Agronomy. p 649-651.

LÄHDESMÄKI, P., AND R. PIISPANEN. 1992. Soil enzymology: role of protective colloid systems in the preservation of exoenzyme activities in soil. Soil Biology and Biochemistry 24:1173-1177.

Littell, R. C., G. A. Milliken, W. W. Stroup, and R. D. Wolfinger. 1996. SAS system for mixed models. Cary, NC: Statistical Analysis Systems Institute Inc.

Martens, D. A., J. B. Johnson, and W. T. Frankenberger, JR. 1992. Production and persistence of soil enzymes with repeated addition of organic residues. Soil Science 53:53-61.

Merlich, A. 1984. Mehlich 3 soil test extractant: a modification of Mehlich 2 extractant. Communications in Soil Science and Plant Analysis 15:1409-1416.

Murphy, J., AND J. P. Riley. 1962. A modified single solution method for the determination of phosphate in natural waters. Analytica Chimica Acta 27: 31-36.

Parham, J. A., S. P. Deng, W. R. Raun, and G. V. Johnson. 2002. Long-term cattle manure application in soil I. Effect on soil phosphorus levels, microbial biomass C, and dehydrogenase and phosphatase activities. Biology and Fertility of Soils 35:328-337.

Reddy, G. B., A. FazA, and R. Bennett, JR., 1987. Activity of enzymes in rhizosphere and non-rhizosphere soils amended with sludge. Soil Biology and Biochemistry 19:203-205.

Richard, C. E., and E. F. Redente. 1995. Nitrogen and phosphorus effects on blue grama and buffalograss interactions. Journal of Range Management 48:417-422.

RichaRdS, J. E. 1993. Chemical characterization of plant tissue. In: M. R. Carter [ED.]. Soil sampling methods of analysis. Boca Raton, FL: Lewis Publishers. $p$ 115-139.

Salema, M. P., C. A. Parker, D. K. Kidby, D. L. Chatel, and T. M. Armitage. 1982. Rupture of nodule bacteria on drying and rehydration. Soil Biology and Biochemistry 14:15-22.

Schwartz, R. C., AND T. H. Dao. 2005. Phosphorus extractability of soils amended with stockpiled and composted cattle manure. Journal of Environmental Quality 34:970-978.

Sharpley, A. N., R. W. McDowell, J. L. Weld, and P. J. A. Kleinman. 2001. Assessing site vulnerability to phosphorus loss in an agricultural watershed. Journal of Environmental Quality 30:206-236.

Speir, T. W., and D. J. Ross. 1978. Soil phosphatase and sulphatase. In: R. G. Burns [ed.]. Soil enzymes. New York, NY: Academic Press. p 198-235.

Stavast, L. J., T. T. Baker, A. L. Ulery, R. P. Flynn, M. K. Wood, and D. S. Cram. 2005. New Mexico blue grama rangeland response to dairy manure application. Rangeland Ecology and Management 58:423-429.

Stewart, B. A., C. A. Robinson, and D. B. Parker. 1998. Manure production and utilization: challenges and opportunities. In: 1998 American Society of Agronomy annual meeting abstracts. Madison, WI: Soil Science Society of America. p 311.

Tabatabal, M. A. 1994. Soil enzymes. In: R. W. Weaver, J. S. Angle, and P. S. Bottomley [EDS.]. Methods of soil analysis, part 2. SSSA book series No. 5 . Madison, WI: Soil Science Society of America.

Tabatabal, M. A., AND J. M. Bremner. 1969. Use of $p$-nitrophenyl phosphate for assay of soil phosphatase activity. Soil Biology and Biochemistry 1:301-307.

Turco, R. F., A. C. Kennedy, and M. D. Jawson. 1994. Microbial indicators of soil quality. In: J. W. Doran, D. C. Coleman, D. F. Bezdicek, and B. A. Stewart [EDS.]. Defining soil quality for a sustainable environment: Proceedings of a symposium sponsored by Divisions S-3, S-6, and S-2 of the Soil Science Society; 4-5 November 1992; Minneapolis, MN. Madison, WI: Soil Science Society Special Publication 35. p 73-90.

[US EPA] US Environmental Protection Agency. 1983. Methods for chemical analysis for water and wastes. EPA/6/4-79-020. Washington, DC: US Government Print Office.

Vuorinen, A. H., And M. H. Saharinem. 1996. Effects of soil organic matter extracted from soil on acid phosphomonoesterase. Soil Biology and Biochemistry 28: 1477-1481.

Wienhold, B. J., J. R. Hendrickson, and J. F. Karn. 2001. Pasture management influences on soil properties in the Northern Great Plains. Journal of Soil and Water Conservation 56:27-31

Wood, C. W., AND J. A. HATTEY. 1995. Impacts of long-term manure applications on soil chemical, microbiological, and physical properties. In: K. Steele [ED.]. Animal waste and the land-water interface. Boca Raton, FL: CRC Press, Lewis Publishers. p 419-428. 